\title{
Risk Analysis of Environmentally Friendly Milk Production Process with GMP and HACCP
}

\author{
Oke Oktavianty ${ }^{1, *}$, Ihwan Hamdala ${ }^{1}$, Wisnu Wijayanto Putro ${ }^{1}$, Effendi bin \\ Mohamad $^{2}$ \\ ${ }^{1}$ Industrial Engineering, Universitas Brawijaya, Malang, Indonesia \\ ${ }^{2}$ Faculty of Manufacturing Engineering, Universiti Teknikal Malaysia Melaka, Malaysia \\ *Corresponding author. Email: okemn7@ub.ac.id
}

\begin{abstract}
Fresh milk is a product that is susceptible to physical, chemical and microbiological contamination. It can cause risks to the food safety of dairy products. In this study, the principles of Good Manufacturing Practices (GMP) and Hazard Analysis Critical Control Points (HACCP) were used to analyze hazards in milk processing. There were 3 processes of Critical Control Point (CCP), namely the process of quality testing, filtering fresh milk with nylon fabric, and packaging. There are 4 recommendations for improvements, namely health and hygiene checking of employees, setting standards of nylon fabric lifetime, as well as recommendations for the $5 \mathrm{~S}$ (housekeeping) implementation. In addition, recommendations for improvements to the cross-section design of the tool used for fresh milk filtering process were made.
\end{abstract}

Keywords: GMP, HACCP, CCP, Fresh Milk

\section{INTRODUCTION}

Indonesia consists of many highland areas with cool air. One of them is Malang Regency, the second largest regency in East Java. As it is located in highlands, Malang is suitable and has a potential in the dairy farming industry. Based on the data from the Central Bureau of Statistics of Malang Regency, in 2016 the population of dairy cattle in Malang was 81,150 , an increase from the previous year which was 78,029. With the increasing population, dairy products have a good potential to improve the economy of the region and the surrounding community

Quality is a factor that must be considered in the development of a product. The quality of a product is very important in the production process [1-4]. In order to maintain the quality of a product, it is necessary to minimize the risk of the product being manufactured to conform to predetermined standards. In the production process risks can be detrimental in various aspects, for example in terms of time and cost, as well as the continuity of the company in the long term if an error occurs during the production process.

Dairy cooperative is a unified system of various elements of society that focuses on milk production and optimization of dairy farming. Dairy cooperatives are mostly engaged in the production of fresh milk, which is supported by the large number of dairy farmers in various regions in Indonesia. In order to increase productivity and maintain the quality of dairy products, dairy cooperatives require risk analysis and management. This is done to avoid negative impacts on the productivity and quality of dairy products, such as products that are not suitable for sale because they are contaminated with chemicals, microbes, packaging equipment, and so on. The right methods to identify, prevent and eliminate these risks are Good Manufacturing Procedure (GMP) and Hazard Analysis and Critical Control Points (HACCP).

GMP is a guideline on how to produce food properly and correctly throughout the production chain, from the primary production stage to the final consumer, and it emphasizes hygiene at every stage. The GMP guidelines comprises factory locations, buildings, final products, 
production equipment, raw materials, employee hygiene, process control, sanitation facilities, labels, product descriptions, storage, maintenance of processing facilities, sanitation activities, laboratories, containers or packaging and transportation [5-7]. Hazard Analysis Critical Control Point (HACCP) is a system to ensure that the safety of food products has been implemented effectively, thus this system can control hazard contributing factors that can reduce the safety level of food products [8-10]. The implementation of a good HACCP system in a production process can be carried out from receiving raw materials, processing, handling, storage, distribution, to after-sales service. This system is focused on food product safety and it can be maintained because HACCP is able to prevent deviation and avoid problems [11-16]. Therefore, it is necessary to conduct this research so that the resulting dairy products are safe for consumption and environmentally-friendly.

\section{RESEARCH METHODS}

The research flow chart can be seen in Figure 1.

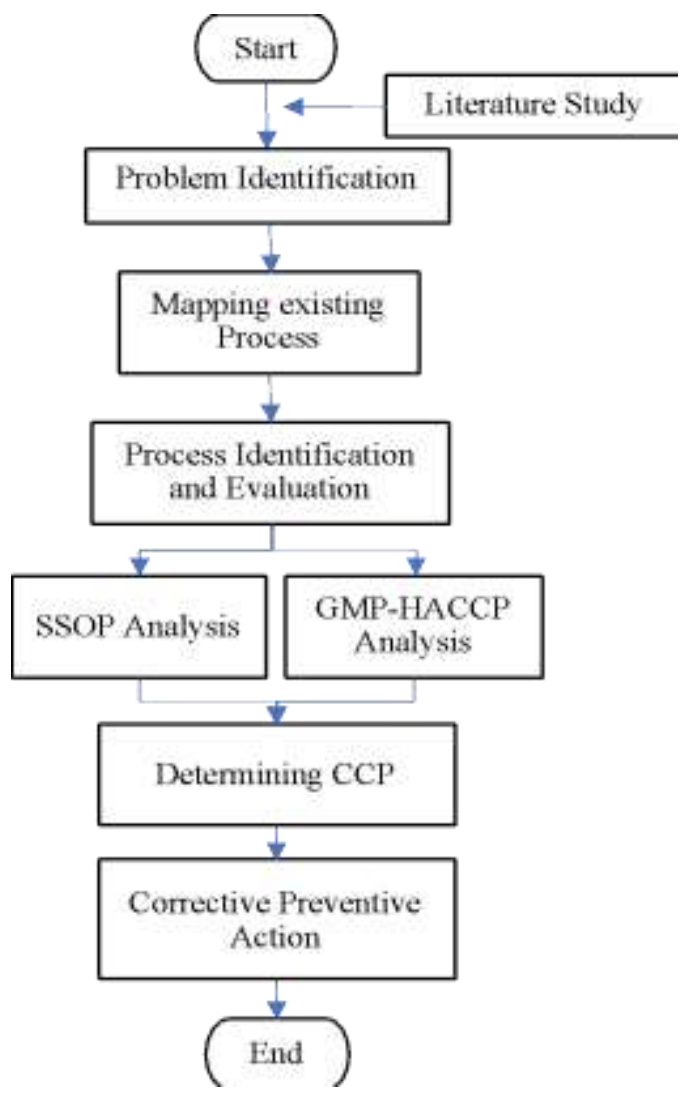

Figure 1 Research Methodology

\section{RESULTS AND DISCUSSION}

The production process can be expressed as a series of activities required to process or change a set of inputs into a number of outputs that have added value. Processing or changes that occur can be physical or non-physical; it can be the shape, dimensions, and properties. The following are the stages of fresh milk production process at SAE Pujon Cooperative dairy unit.

One of the stages in HACCP is a process flow diagram that describes the operational stages in the manufacture of a product. This flow diagram is very important to identify potential hazards that may arise. Process flow diagrams can be compiled after direct observation of fresh milk products. The process flow diagram for fresh dairy products can be seen in Figure 2 .

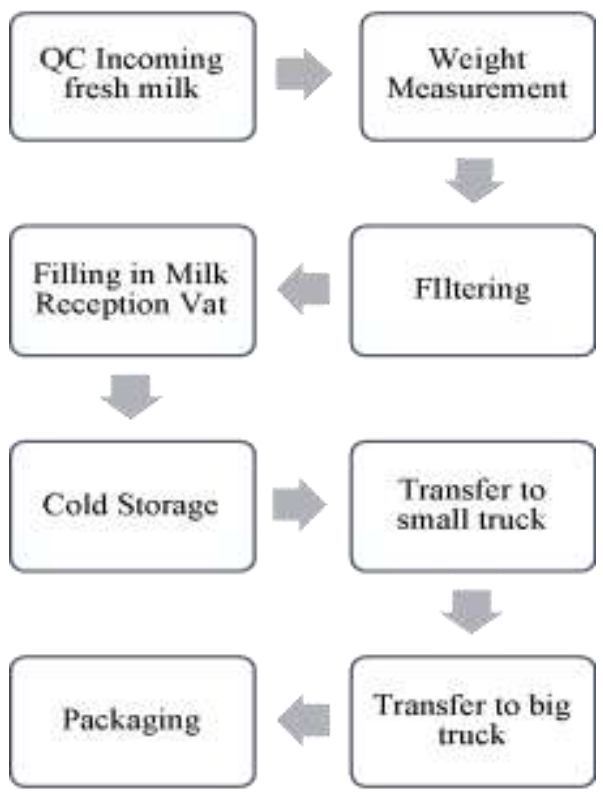

Figure 2 Fresh Milk Production Flow Diagram

\subsection{Hazard Analysis}

Hazard analysis is a systematic evaluation of specific foods and raw materials to determine risks. Food safety risks that must be examined are: chemical contamination safety aspects, physical contamination safety aspects, and biological contamination safety aspects including microbiology.

Hazard analysis stage is a critical stage before it can be determined whether a certain stage is a CCP or not. Hazard determination is carried out at each stage of the production process so that all possible hazards that arise in each process can be recognized. Upon knowing the potential hazards, the next step is taking preventive measures to control them. Hazard analysis and preventive measures can be seen in Table 1 . 
Table 1. Hazard Analysis in the Process of Fresh Milk Production

\begin{tabular}{|c|c|c|c|c|c|c|}
\hline \multirow[b]{2}{*}{ Stages } & \multirow[b]{2}{*}{ Hazard Potentials } & \multirow[b]{2}{*}{ Causes of Hazard } & \multicolumn{3}{|c|}{ Risk Analysis } & \multirow[b]{2}{*}{ Prevention } \\
\hline & & & Severity & Opportunity & $\begin{array}{l}\text { Risk } \\
\text { Factor }\end{array}$ & \\
\hline \multirow{3}{*}{$\begin{array}{l}\text { Reception of } \\
\text { Fresh Milk } \\
\text { from } \\
\text { Farmers }\end{array}$} & $\begin{array}{l}\text { Microbiological } \\
\text { Hazard (Eschericia } \\
\text { coli, Salmonella, } \\
\text { Staphylcoccus } \\
\text { aureus) }\end{array}$ & $\begin{array}{l}\text { Bacteria } \\
\text { contamination from } \\
\text { the surrounding } \\
\text { environment when } \\
\text { milk is poured }\end{array}$ & $\mathrm{T}$ & $\mathrm{S}$ & $\mathrm{T}$ & $\begin{array}{l}\text { - Correct SOP } \\
\text { implementatio } \\
\mathrm{n} \\
\text { - Equipment } \\
\text { must be } \\
\text { sterilized } \\
\text { every time }\end{array}$ \\
\hline & $\begin{array}{l}\text { Physical Hazard } \\
\text { (dust, soil, sand) }\end{array}$ & $\begin{array}{l}\text { Sand contamination } \\
\text { when milk is poured } \\
\text { into milk can }\end{array}$ & $\mathrm{R}$ & $\mathrm{S}$ & $\mathrm{R}$ & $\begin{array}{l}\text { Hygienization } \\
\text { in milk } \\
\text { pouring } \\
\text { process }\end{array}$ \\
\hline & No. & Unsterile milk can & $\mathrm{R}$ & $\mathrm{S}$ & $\mathrm{R}$ & $\begin{array}{l}\text { - Washing of } \\
\text { equipment } \\
\text { after use } \\
\end{array}$ \\
\hline \multirow{3}{*}{$\begin{array}{l}\text { Quality } \\
\text { Inspection }\end{array}$} & $\begin{array}{l}\text { Physical Hazard } \\
\text { (dirt, dust, sand) }\end{array}$ & $\begin{array}{l}\text { Negligence at the } \\
\text { time of sampling. } \\
\text { Limited facilities and } \\
\text { infrastructure }\end{array}$ & $\mathrm{R}$ & $\mathrm{R}$ & $\mathrm{R}$ & \multirow{3}{*}{$\begin{array}{l}\text { - Re-filtering } \\
\text { with a sterile } \\
\text { cloth } \\
\text { - Sterilization } \\
\text { of equipment } \\
\text { must be } \\
\text { carried out } \\
\text { before and } \\
\text { after testing } \\
\text { - Workers must } \\
\text { apply the SOP } \\
\text { that has been } \\
\text { determined }\end{array}$} \\
\hline & Chemical Hazard & $\begin{array}{l}\text { Antibiotic residue } \\
\text { from Cow feed }\end{array}$ & $\mathrm{R}$ & $\mathrm{S}$ & $\mathrm{R}$ & \\
\hline & $\begin{array}{l}\text { Microbiological } \\
\text { Hazard }\end{array}$ & $\begin{array}{l}\text { Unsterile equipment } \\
\text { Cross contamination } \\
\text { from workers }\end{array}$ & $S$ & $\mathrm{R}$ & $\mathrm{S}$ & \\
\hline \multirow{2}{*}{$\begin{array}{l}\text { Weighing } \\
\text { milk using } \\
\text { Milk } \\
\text { Reception } \\
\text { Scale }\end{array}$} & Physical Hazard & $\begin{array}{l}\text { Scales are rarely } \\
\text { cleaned due to } \\
\text { frequent use }\end{array}$ & $\mathrm{R}$ & $\mathrm{R}$ & $\mathrm{R}$ & $\begin{array}{l}\text { Periodic scale } \\
\text { cleaning }\end{array}$ \\
\hline & $\begin{array}{l}\text { Microbiological } \\
\text { Hazard }\end{array}$ & $\begin{array}{l}\text { Scales are } \\
\text { contaminated by } \\
\text { bacteria }\end{array}$ & $\mathrm{R}$ & $\mathrm{S}$ & $\mathrm{R}$ & $\begin{array}{l}\text { Addition of a } \\
\text { weighing plate } \\
\text { coating tool }\end{array}$ \\
\hline \multirow{2}{*}{$\begin{array}{l}\text { Filtration } \\
\text { using nylon } \\
\text { fabric }\end{array}$} & $\begin{array}{l}\text { Microbiological } \\
\text { Hazard }\end{array}$ & Unsterile equipments & $\mathrm{S}$ & $\mathrm{S}$ & $\mathrm{S}$ & $\begin{array}{l}\text { Use of sterilized } \\
\text { tools }\end{array}$ \\
\hline & Chemical Hazard & $\begin{array}{l}\text { Nylon filters are } \\
\text { rarely changed } \\
\text { during use }\end{array}$ & $\mathrm{R}$ & $\mathrm{R}$ & $\mathrm{R}$ & $\begin{array}{l}\text { Regular change } \\
\text { of tools }\end{array}$ \\
\hline $\begin{array}{l}\text { Collecting } \\
\text { milk in Milk } \\
\text { Reception } \\
\text { Vat }\end{array}$ & $\begin{array}{l}\text { Microbiological } \\
\text { Hazard }\end{array}$ & Unsterile tank & $\mathrm{R}$ & $\mathrm{R}$ & $\mathrm{R}$ & $\begin{array}{l}\text { Use of sterilized } \\
\text { tools }\end{array}$ \\
\hline $\begin{array}{l}\text { Cooling up } \\
\text { to } 4^{\circ} \mathrm{C}\end{array}$ & $\begin{array}{l}\text { Microbiological } \\
\text { Hazard }\end{array}$ & $\begin{array}{l}\text { Unsuitable } \\
\text { temperature }\end{array}$ & $S$ & $\mathrm{R}$ & $\mathrm{S}$ & $\begin{array}{l}\text { Periodic } \\
\text { temperature } \\
\text { checking } \\
\end{array}$ \\
\hline $\begin{array}{l}\text { Storage tank } \\
\text { at } 4^{\circ} \mathrm{C}\end{array}$ & $\begin{array}{l}\text { Microbiological } \\
\text { Hazard }\end{array}$ & Unsterile equipment & $\mathrm{R}$ & $\mathrm{R}$ & $\mathrm{R}$ & $\begin{array}{l}\text { Sterilization is } \\
\text { done before the } \\
\text { milk is poured } \\
\text { into the storage } \\
\text { tank }\end{array}$ \\
\hline $\begin{array}{l}\text { Distribution } \\
\text { using 800- } \\
\text { liter tank } \\
\text { truck }\end{array}$ & Physical Hazard & $\begin{array}{l}\text { The outside air } \\
\text { temperature enters } \\
\text { the potential gap of } \\
\text { the tank }\end{array}$ & S & $\mathrm{R}$ & $\mathrm{S}$ & $\begin{array}{l}\text { Regular } \\
\text { maintenance of } \\
\text { the tank } \\
\text { condition }\end{array}$ \\
\hline
\end{tabular}




\begin{tabular}{|c|c|c|c|c|c|c|}
\hline \multirow[b]{2}{*}{ Stages } & \multirow[b]{2}{*}{ Hazard Potentials } & \multirow[b]{2}{*}{ Causes of Hazard } & \multicolumn{3}{|c|}{ Risk Analysis } & \multirow[b]{2}{*}{ Prevention } \\
\hline & & & Severity & Opportunity & $\begin{array}{c}\text { Risk } \\
\text { Factor }\end{array}$ & \\
\hline & Chemical Hazard & $\begin{array}{l}\text { The tank contains } \\
\text { soap residue from } \\
\text { cleaning process }\end{array}$ & $\mathrm{R}$ & $\mathrm{R}$ & $\mathrm{R}$ & $\begin{array}{l}\text { Tank drying } \\
\text { after cleaning }\end{array}$ \\
\hline $\begin{array}{l}\text { Transferring } \\
\text { fresh milk } \\
\text { from small } \\
\text { truck to } \\
\text { bigger truck }\end{array}$ & $\begin{array}{l}\text { Physical Hazard } \\
\text { (dust, remains of } \\
\text { fresh milk in the } \\
\text { tank truck) }\end{array}$ & Unsterile equipment & $\mathrm{S}$ & $\mathrm{R}$ & $S$ & $\begin{array}{l}\text { Sterilization } \\
\text { before loading } \\
\text { the milk into the } \\
\text { truck }\end{array}$ \\
\hline \multirow[b]{3}{*}{ Packaging } & $\begin{array}{l}\text { Physical Hazard } \\
\text { (dust, dirt) }\end{array}$ & $\begin{array}{l}\text { Cross contamination } \\
\text { from workers and } \\
\text { unsterile equipment }\end{array}$ & $S$ & $S$ & $S$ & \multirow{3}{*}{$\begin{array}{l}\text { - Unpackaged } \\
\text { milk is placed } \\
\text { in a tightly } \\
\text { closed } \\
\text { container } \\
\text { - Employee } \\
\text { Hygiene } \\
\text { - Process } \\
\text { Hygiene } \\
\text { - Tool } \\
\text { Sterilization } \\
\text { - Use of safe } \\
\text { packaging } \\
\text { materials } \\
\text { - Packaging } \\
\text { must be } \\
\text { sterilized first }\end{array}$} \\
\hline & $\begin{array}{l}\text { Microbiological } \\
\text { Hazard }\end{array}$ & $\begin{array}{l}\text { Milk can is opened } \\
\text { for too long during } \\
\text { filling process }\end{array}$ & $S$ & $\mathrm{R}$ & $S$ & \\
\hline & Chemical Hazard & Unsafe packaging & $S$ & $S$ & $S$ & \\
\hline
\end{tabular}

In addition to the hazard analysis, the determination of the risk level is also carried out. It is conducted to clarify the determination of hazard groups and risk category of the product. The determination of product risk level is shown in Table 2. Based on Table 2, it shows that the fresh milk in SAE Pujon Cooperative is of moderate risk because this ingredient is only associated with 3 hazard groups, namely hazard groups $\mathrm{B}, \mathrm{D}$, and $\mathrm{E}$.

Table 2. Determination of Product Risk Level

\begin{tabular}{|l|c|c|c|c|c|c|c|}
\hline \multirow{2}{*}{$\begin{array}{l}\text { Raw } \\
\text { Materials }\end{array}$} & \multicolumn{4}{|l|}{ Hazard Groups } & \multicolumn{2}{|l|}{$\begin{array}{l}\text { Risk } \\
\text { Category }\end{array}$} \\
\cline { 2 - 8 } & A & B & C & D & E & F & \\
\hline $\begin{array}{l}\text { Fresh } \\
\text { Milk }\end{array}$ & 0 & + & 0 & + & + & 0 & III \\
\hline
\end{tabular}

Hazard group B is a product containing materials sensitive to biological, chemical and physical hazards [17]. Fresh milk is included in hazard group B because fresh milk contains nutrients that can be contaminated by microorganisms if the handling does not follow the correct SOP. Pathogenic microorganisms that often contaminate milk are Brucella, Salmonella, Mycobacterium, Eschericia coli, Bacillus sp, Staphylcoccus aureus and Clostridium sp. Fresh milk is also vulnerable to the physical hazards that can occur during the transportation and reception of milk. In addition to fresh milk, additives such as dyes, flavors, stabilizers and cocoa powder are also included in hazard group B. The four additives are included in group B because they are considered to have chemical hazards if they do not meet the standards and the types used are not suitable.

Hazard group D is the product with the possibility of recontamination after going through the processing but before packaging takes place. Fresh milk is a product that is very susceptible to microorganisms. When the handling is not in accordance with the SOP it will cause the product to be contaminated by microorganisms, so it is hoped that the product is carefully handled by keeping the milk cold. Hazard group $\mathrm{E}$ means that there is the possibility of recontamination or improper handling during distribution, sale or handling by consumers, so that the product is harmful for consumption. It is important to ensure the customer satisfaction can be reach [18]. 


\subsection{Determination of CCP}

One part of HACCP is the establishment of a CCP (Critical Control Point), a specific point in the food system that can cause a risk to human health if loss of control occurs at that specific point. The second principle of HACCP can be carried out by conducting an analysis using CCP decision tree for each stage of fresh milk production process. In the decision tree there are four questions arranged in sequence and designed to objectively assess the existing CCPs and to identify which stages are required to control the identified potential hazards. The questions are as follows.

Q1: Have any controls been implemented?
Q2: Is this stage designed to eliminate or reduce potential hazards to an acceptable level?

Q3: Does the contamination with the identified hazard exceed an acceptable level, or can it increase to an unacceptable level?

Q4: Is it possible to eliminate or reduce the identified hazard at a later stage, or is it possible to reduce the level of hazard probability to an acceptable level?

The four questions contained in the CCP decision tree as shown in Figure 5.3 is the guidance for determining CCP for each stage of the process of fresh milk production. The results of this analysis can be seen in Table 3.

Table 3. CCP in the Process of Fresh Milk Production

\begin{tabular}{|c|c|c|c|c|c|c|c|}
\hline Stages & Hazard & Preventative Measures & P1 & $\mathrm{P} 2$ & $\mathrm{P} 3$ & $\mathrm{P} 4$ & CCP \\
\hline $\begin{array}{l}\text { Reception of } \\
\text { Raw Materials }\end{array}$ & $\begin{array}{l}\text { Microorganism } \\
\text { contamination }\end{array}$ & $\begin{array}{l}\text { Precise SOP } \\
\text { implementation and } \\
\text { equipment must be } \\
\text { sterilized every time }\end{array}$ & No & No & - & - & - \\
\hline $\begin{array}{l}\text { Quality } \\
\text { Inspection }\end{array}$ & $\begin{array}{l}\text { Microorganism } \\
\text { contamination }\end{array}$ & $\begin{array}{l}\text { Employees must implement } \\
\text { the SOP }\end{array}$ & Yes & Yes & - & - & $\mathrm{CCP}$ \\
\hline $\begin{array}{l}\text { Weighing milk } \\
\text { using Milk } \\
\text { Reception Scale }\end{array}$ & $\begin{array}{l}\text { Microorganism } \\
\text { contamination }\end{array}$ & $\begin{array}{l}\text { Tool sterilization before and } \\
\text { after use }\end{array}$ & No & - & - & - & - \\
\hline $\begin{array}{l}\text { Filtration using } \\
\text { nylon fabric }\end{array}$ & $\begin{array}{l}\text { Microorganism } \\
\text { contamination }\end{array}$ & $\begin{array}{l}\text { Tool sterilization before and } \\
\text { after use }\end{array}$ & Yes & Yes & - & - & $\mathrm{CCP}$ \\
\hline $\begin{array}{l}\text { Collecting milk } \\
\text { in Milk } \\
\text { Reception Vat }\end{array}$ & $\begin{array}{l}\text { Microorganism } \\
\text { contamination }\end{array}$ & $\begin{array}{l}\text { Use of tools that have been } \\
\text { sterilized }\end{array}$ & No & - & - & - & - \\
\hline $\begin{array}{l}\text { Colling up to } \\
4^{\circ} \mathrm{C}\end{array}$ & $\begin{array}{l}\text { Microorganism } \\
\text { contamination } \\
\text { due to unsuitable } \\
\text { temperature }\end{array}$ & $\begin{array}{l}\text { Periodic temperature } \\
\text { checking }\end{array}$ & Yes & No & No & - & - \\
\hline $\begin{array}{l}\text { Storage Tank } \\
\left(4^{\circ} \mathrm{C}\right)\end{array}$ & $\begin{array}{l}\text { Temperature } \\
\text { Fluctuations }\end{array}$ & $\begin{array}{l}\text { Periodic temperature } \\
\text { checking }\end{array}$ & Yes & No & No & - & - \\
\hline $\begin{array}{l}\text { Distribution } \\
\text { using } 800 \text { liter } \\
\text { tank truck }\end{array}$ & $\begin{array}{l}\text { Microorganism } \\
\text { contamination }\end{array}$ & $\begin{array}{l}\text { Sterilization before loading } \\
\text { the milk into the truck }\end{array}$ & Yes & No & No & - & - \\
\hline $\begin{array}{l}\text { Transferring } \\
\text { fresh milk from } \\
\text { small truck to } \\
\text { bigger truck }\end{array}$ & $\begin{array}{l}\text { Microorganism } \\
\text { contamination }\end{array}$ & $\begin{array}{l}\text { Sterilization before loading } \\
\text { the milk into the truck }\end{array}$ & Yes & No & Yes & No & - \\
\hline Milk Packaging & $\begin{array}{l}\text { Microorganism } \\
\text { contamination due } \\
\text { to milk filling } \\
\text { duration }\end{array}$ & $\begin{array}{l}\text { Milk filling must be done } \\
\text { in timely manner } \\
\text { Employee Hygiene } \\
\text { Tool Sterilization }\end{array}$ & Yes & No & Yes & NO & $\mathrm{CCP}$ \\
\hline
\end{tabular}




\subsection{CCP Analysis}

Based on the identification of critical control points (CCP), there are four processes where $\mathrm{CCP}$ involves, namely the process of receiving raw materials, quality inspection, filtering milk with nylon cloth, and milk packaging, as described below.

a. Quality inspection process (Figure 3). In this process, the potential hazard occurs during the process of measuring the specific density and testing the coagulation of milk. This is because at the time of testing, employees use their bare hands to close the holes in the lactodensimeter, meaning there is direct contact between the employee's hands and fresh milk. Fresh milk that has been tested and exposed to direct contact is then placed in a small container and put back into the milk can owned by the farmers to be poured into the filter. As a result, fresh milk that is exposed to direct contact can potentially be contaminated with bacteria both physically and microbiologically and it can affect the overall milk quality. In this process, it is necessary to employ work discipline and change the SOP so that the milk that has been tested not be added to the milk can.

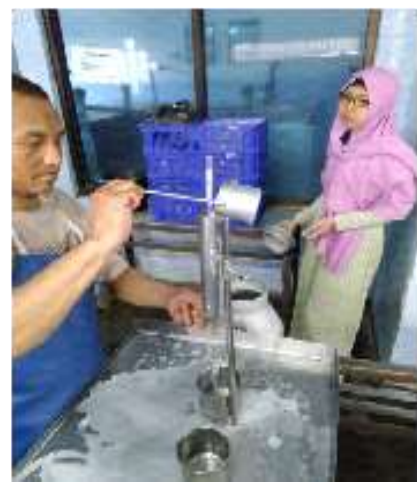

Figure 3 Quality inspection process

b. Milk filtering with nylon fabric (Figure 4). This process can have potential hazards caused by the condition of the nylon fabric used as the milk filter. If the nylon filter cloth is not clean and sterile, it can pose a danger to the condition of the milk being poured and exposed to the filter. In this process, it is necessary to employ work discipline and change tools or nylon filter periodically within a period of 2 to 3 days of use.

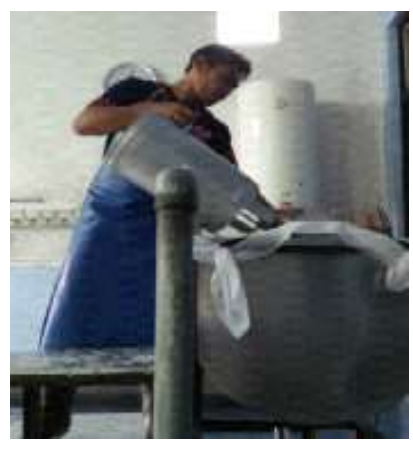

Figure 4 Milk filtering with nylon fabric

c. Milk packaging (Figure 5). In this process, workers do not wear a complete uniform that should be worn during the milk packaging process. In addition, there is also a potential hazard because milk in milk can is left open for a long time. The milk is exposed to air containing microorganisms while waiting to be poured into the packaging, and this can pose a danger of physical contamination such as dust and dirt, as well as a biological hazard because it can cause bacteria to grow. If there is contamination by microorganisms from the air into the milk, then there is no other process that can remove these contaminants before they are received by consumers. Milk that is ready for packaging should be stored in a closed milk can. The process that becomes the CCP must be carried out correctly according to the SSOP and strict control is required to eliminate and prevent potential hazards that occur. Negligence when carrying out some processes can pose a danger to the production system.

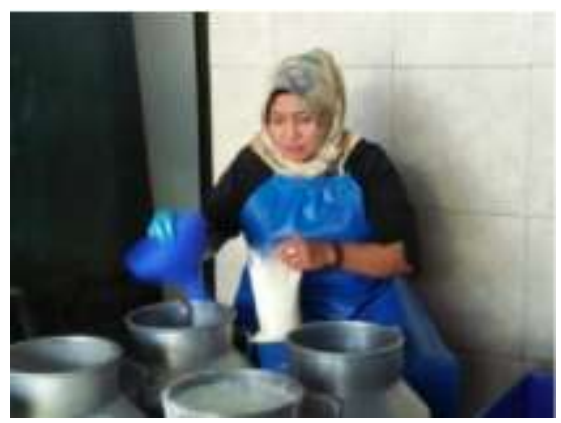

Figure 5 Milk packaging

\subsection{Recommendations for Improvement}

After analysis using the GMP and HACCP methods, in the identification of CCP three points which become the critical points in fresh milk production process are obtained. At this stage, a suggestion for improvement is given and it aims to adjust the aspects of GMP implementation to the specified requirements in order to 
minimize hazard risks that can compromise the safety of fresh milk products. Following are the recommendations for improvement that can be implemented in work procedure at SAE Pujon:

a. Recommendations for checking the health and hygiene of employees.

The health of employees is an important aspect that must be considered by cooperatives to maintain the safety of the dairy products they produce. Employee health also has an important role in the production of healthy fresh milk products as employees directly interact with the raw materials. The interactions vary from handling of raw materials, for example during the quality testing process. Regulations regarding permit for sick employees to enter the production floor are very important to note because this can trigger product contamination. Employees with contagious diseases who work directly with food have the potential to transmit the disease through food. To find out whether employees are sick or not and are still within the tolerance limit to be allowed to work, it is necessary to perform periodic checking to employees to determine the health of the employees on duty. In addition, there must also be direction to all employees to comply with the applicable regulations and SOPs such as employee hygiene. Employees should use head coverings to protect dairy products from hair, masks and gloves to protect processed foods from unwanted bacterial contamination. The application of good hygiene is an effort to prevent food contamination from physical, chemical, or biological contaminants from the body. This is supposed to be cultivated as good employee habits in the application of hygiene. The examples of good employee habits are always keeping the body clean by taking a shower before going to work, always working attentively and not eating food while working, always keeping the work environment clean, and always wearing complete uniform. On the other hands, employees sometimes have bad habits such as spitting, talking while working, sneezing and coughing in front of processed materials, and chewing food while working or smoking in the work environment. These should be avoided to ensure the safety of the product.

b. Recommendations regarding supporting equipment.

To avoid unwanted biological reactions between milk and remains of milk, the nylon filter cloth should be washed thoroughly and replaced regularly with a maximum of every 3 days of use. In addition, during milk packaging process, milk cans that have not been processed should not be left open to prevent physical or biological contamination. When milk is poured into the packaging using a funnel, the funnel should be made of aluminum, not plastic. In accordance with GMP and SSOP, tools that are in direct contact with food products should be made of aluminum.

c. Recommendations regarding the implementation of 5S culture:
1) Seiri (concise): It refers to sorting useful and useless items by marking items that are no longer useful with labels and then removing them from the workplace. SAE Pujon can provide markers in the form of labels to items such as unused fabrics and items that should not be placed on the production floor. Such objects can also interfere with the comfort and the cleanliness of the food products.

2) Seiton (neat): It refers to the arrangement of useful items so that they are easy to find and safe. And it is necessary to give an indication or explanation of the place, name of the item, and the amount of the item. Therefore, when the item is about to be used, it can be accessed easily and quickly. SAE Pujon can place all quality inspection equipment in a certain cupboard. By doing so, it is expected that the equipment can be searched, found and retrieved easily so that productivity can increase.

3) Seiso (clean): It refers to cleaning of items that have been neatly arranged so as not to get dirty, and this includes the workplace, the environment as well as the equipment. The cleanliness of the production floor must also be maintained by cleaning milk that is spilled on the floor.

4) Seiketsu (caring): It refers to maintaining a neat and clean work environment as a standard of work. The condition that has been achieved in seiri, seiton, and seiso processes must be standardized. These standards should be easy to understand, implemented throughout the organization, and checked regularly and periodically. SAE Pujon should maintain the $3 \mathrm{~S}$ discussed earlier by: maintaining cleanliness on the production floor, applying employee discipline by returning tools that have been used to their original places, and removing items that are not used from the workplace.

5) Shitsuke (diligent): self-awareness of work ethics such as discipline to standards, feeling ashamed if violating rules and feeling happy when making improvements. In SAE Pujon weekly or monthly audits are needed in order to keep the work environment clean, conducive, and comfortable for workers and to maintain the hygiene of the processed milk.

d. Recommended cross-section design for filtering fresh milk

The filtering machine for fresh milk was designed and can be seen in Figure 6. 


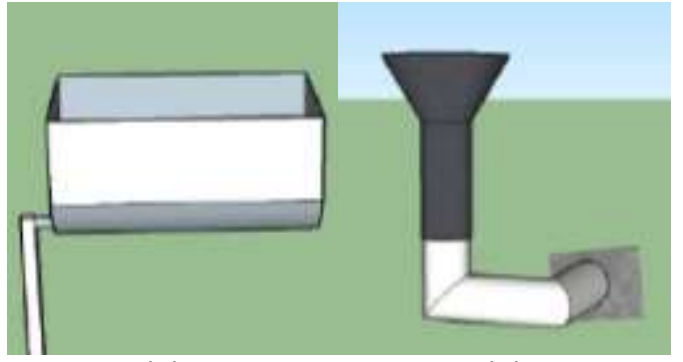

(a)

(b)

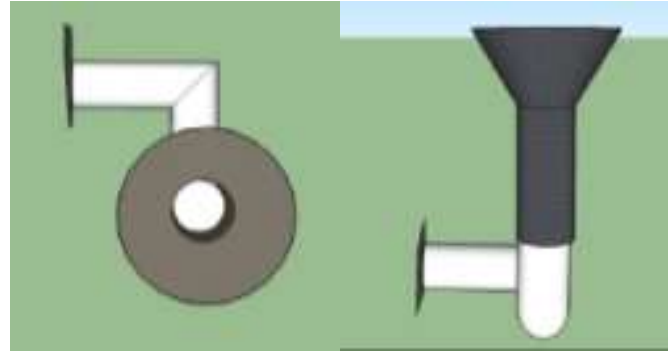

(c)

(d)

Figure 6 Cross-section design for filtering fresh milk. (a) Old design, (b) New design (side perspective), (c) New design (top perspective), and (d) New design (front perspective)

\section{CONCLUSION}

Based on the results of the analysis and discussion that has been carried out, the following conclusions can be drawn. Food safety risks that must be examined in the fresh milk production process include: chemical contamination safety aspects, physical contamination safety aspects, and biological contamination safety aspects including microbiology. Fresh milk contains nutrients that can be contaminated by microorganisms if the handling does not follow the correct SOP. Pathogenic microorganisms that often contaminate milk are Brucella, Salmonella, Mycobacterium, Eschericia coli, Bacillus sp, Staphylcoccus aureus and Clostridium $s p$. Fresh milk is also vulnerable to the physical hazards that can occur during the transportation and reception of milk.

The results of identification of critical points which consist of 10 processes result in 3 processes that become the CCP or critical points, namely: quality testing process, filtering fresh milk with nylon fabric, and packaging. It can be seen that the in the quality testing process there are: physical contamination caused by foreign body contamination, chemical contamination caused by cow feed antibiotic residues, and biological contamination caused by pathogenic bacteria due to direct contact with the hands of workers. The next is the process of filtering fresh milk that possesses the hazard of biological contamination, namely pathogenic bacteria due to unsterile nylon cloth, and chemical contamination caused by the residue of cleaning soap for the nylon fabric. Furthermore, the contaminants in the packaging process are: physical contamination, i.e. dust and dirt due to cross-contamination from workers and unsterile equipment, biological contamination namely pathogenic bacteria originating from the air because milk cans are opened for too long during the process of filling milk into the packaging, and chemical contamination caused by non-sterile packaging materials. Processes serving as the $\mathrm{CCP}$ must be carried out correctly and control is required to eliminate and prevent potential hazards that occur. Negligence when carrying out some processes can pose a danger to the production system.

There are four recommendations for improvement, one of which is recommendation for checking employee health and employee hygiene as it is necessary to check the employees periodically to determine the health of employees on duty. In addition, there must also be direction to all employees to comply with applicable regulations and SOPs, such as employee hygiene. Employees should use head coverings to protect dairy products from hair, masks and gloves to protect processed foods from unwanted bacterial contamination. Recommendations related to supporting equipment are the use and replacement of nylon cloth for regular milk filtration and replacement of the plastic funnel for pouring milk to funnel made of aluminum. Recommendations for the application of $5 \mathrm{~S}$ culture are concise, neat, clean, and caring which have been widely implemented by large companies. SAE Pujon Cooperative is expected to have a dynamic, comfortable and neat working atmosphere. Lastly, it is recommended to employ cross-sectional design for filtering fresh milk where the cross-section is designed to be smaller than the existing one in order to minimize contamination from physical contaminants such as dust and other impurities to ensure the safety of fresh milk products.

\section{ACKNOWLEDGMENTS}

The authors express their gratitude BPPM FT UB who funded this study through the Grant scheme.

\section{REFERENCES}

[1] C.M. Borror, The certified quality engineer handbook, ASQ Quality Press, America, 2009.

[2] D.A. Garvin, Managing quality, The Free Press, New York, 1987.

[3] V. Gaspersz, Total quality management, PT. Gramedia Pustaka Utama, Jakarta, 2005.

[4] D.L. Goetsch, S. Davis, Introduction to total quality, quality, productivity, competitiveness, Englewood Cliffs, NJ, Prentice Hall International Inc, 1994. 
[5] [CAC] Codex Alimentarius Comission, Recommended international code of practice general principles of food hygiene, Food and Agriculture Organization of The United Nations World Health Organization, Rome, 1991.

[6] S. Motimor, C. Wallace, HACCP. A practical approach. Revisited with a view of food safety risk reduction: Springer, 1994.

[7] D.A. Corlett, Overview of biological, chemical, and physical hazard, In: Pierson, DM. dan DA. Corlett, Jr. (eds.), HACCP Principles and Aplications. Chapman and Hall, New York, p. 27, 1992.

[8] Fardiaz, Fardiaz, Proyek makanan jajanan. materi semiloka program intervensi pembinaan usaha makanan jajanan, Lembaga Pengabdian Kepada Masyarlwakat (LPM- IPB), 1994.

[9] FDA, U.S. Food and drug administration center for food safety and applied nutrition, Foodborne, Pathogenic Microorganism and Natural Toxins Handbook, 1992, http://www.cfsan.fda.gov/ mow/app3a.html Acessed on 10th April 2018

[10] D.J. Frame, Managing risk in organization. san fransisco, Josey-Bass, 2003.
[11] Haryadi, Sistem analisa bahaya dan pengendalian titik kritis (HACCP), Makalah Training HACCP, Bogor, 2001.

[12] A. M. Katsuyama, M. Jantschke, M, Sanitation and standard operating procedures, In : K.E. Stevenson, D.T. Bernard, editor. HACCP : A Systematic approach to food safety, third edition, Washington, DC: The Food Processors Institute, pp. 31-37, 1999.

[13] S. Mortimore, C. Wallace, HACCP: a Practical approach. Chapman and Hall, London, 1995.

[14] NACMCF, HACCP Principles for food production, USDA-FSIS Information Office, Washington DC, 1992.

[15] M.D. Pierson, D.A Corlett, HACCP Principles and Application, An Avi Book. New York, 1992.

[16] H. Thaheer, Sistem manajemen HACCP, Bumi Aksara, Jakarta, 2005.

[17] Codex General Standard For Contaminants And Toxins In Foods Codex Stan 193, p 1-20, 1995

[18] F. Tjiptono, G. Chandra, Service, quality \& satisfaction, Andi, Yogyakarta, 2011. 